\title{
Body weight, semen quality, and age at sperm production of hemicastrated and intact cockerels (Gallus domesticus)
}

\author{
G. I. Onuora \\ Department of Veterinary Physiology \& Pharmacology, Faculty of Veterinary Medicine, \\ University of Nigeria, Nsukka, Nigeria
}

\begin{abstract}
Summary. Spermatozoa were found earlier in the ejaculates of hemicastrated cockerels and the mean body weight of the hemicastrates was significantly $(P<0.01)$ greater than that of the intact cockerels. The mean values for sperm concentration $/ \mathrm{ml}$, and total spermatozoa in the ejaculates of the hemicastrates were significantly greater $(P<0 \cdot 01)$ than those of the intact cockerels. Differences existed between the hemicastrates bearing the left testis, and those bearing the right testis in respect of age at sperm production, sperm/concentration and total spermatozoa in the ejaculate.
\end{abstract}

\section{Introduction}

Hemicastration increases plasma gonadotrophin concentration in cockerels (Wilson \& de Reviers, 1979), with consequent enhancement of spermatogenesis (Onuora, 1985).

Differences in size of the left and right testis have been observed in cockerels (Witschi, 1935; Romonoff, 1960). Witschi (1935) suggested that this difference was due to the larger number of germ cells which migrate to the primordial left testis on the 4th day of incubation. Onuora (1987) determined when spermatozoa were first found in the macerated tissues of the testes of hemicastrates bearing the left testes, hemicastrates bearing the right testes and intact cockerels, and reported that spermatozoa were found earlier in these tissues in the following order: left testis remaining in hemicastrate, right testis remaining in hemicastrate, left testis of intact cockerel and right testis of intact cockerel. Removal of the right testis might then be expected to lead to early sperm production.

The aim of the present study was to determine when spermatozoa could be obtained from the ejaculates of hemicastrated and intact cockerels, and to compare the quality of the semen obtained from these cockerels.

\section{Materials and Methods}

Commercial Babcock chicks were reared in deep litter and fed broiler starter (containing $21 \cdot 0 \%$ crude protein, $3 \cdot 2 \%$ oil, $4.2 \%$ fibre and supplemented with vitamins and minerals) and water freely. At 5 weeks of age just before hemicastration the birds were arbitrarily divided into three groups of 15 each. Hemicastration was carried out surgically after infiltration of $2 \%$ xylocaine (Astra, Sweden) into the last intercostal space. All the birds were hemicastrated within $24 \mathrm{~h}$, alternating between birds in Group HLT and birds in Group HRT. During hemicastration there were some deaths. Finally each group was made up of 10 birds having a mean body weight of $0.41 \pm 0.05$ for hemicastrates bearing the left testis (Group HLT), $0.39 \pm 0.15$ for hemicastrates bearing the right testis (Group HRT) and $0.42 \pm 0.08 \mathrm{~kg}$ for intact birds (Group CT). At 10 weeks of age all the cockerels were put into individual cages and fed broiler finisher diet (containing $19 \cdot 0 \%$ crude protein, $4.0 \%$ oil, $4 \cdot 2 \%$ fibre, and supplemented with vitamins and minerals) and water freely until the end of the study.

From 12 weeks of age ejaculates were collected at intervals of 2 days (i.e. 3 times a week) using the massage technique of Burrows \& Quinn (1935). The mean body weight of the groups was determined weekly from 12 weeks of age. Initially smears made from the ejaculates were stained with eosin/nigrosin, and searched for the presence of spermatozoa (Cooper \& Rowell, 1958). When spermatozoa had been found in all the ejaculates of all the cockerels, the semen samples were thereafter evaluated for sperm concentration, motility, percentage of abnormal spermatozoa, total spermatozoa in the ejaculate and volume of semen. In total, 18 ejaculates were collected before and 33 after spermatozoa were found in the ejaculates of all the birds. The latter data were analysed using Student's $t$ test. 
Table 1. Number of hemicastrated and intact cockerels and age at which spermatozoa were found in their ejaculates

\begin{tabular}{lccc}
\hline Age (days) & $\begin{array}{c}\text { Group HRT } \\
(N=10)\end{array}$ & $\begin{array}{c}\text { Group HLT } \\
(N=10)\end{array}$ & $\begin{array}{c}\text { Group CT } \\
(N=10)\end{array}$ \\
\hline 111 & 7 & 3 & 0 \\
121 & 8 & 6 & 2 \\
126 & 8 & 7 & 3 \\
129 & 9 & 7 & 3 \\
136 & 9 & 10 & 7 \\
147 & 10 & - & 8 \\
150 & - & - & 10 \\
\hline
\end{tabular}

Ejaculates were collected 3 times a week from hemicastrates bearing the right testis (Group HRT), hemicastrates bearing the left testis (Group HLT) and intact cockerels (Group CT).

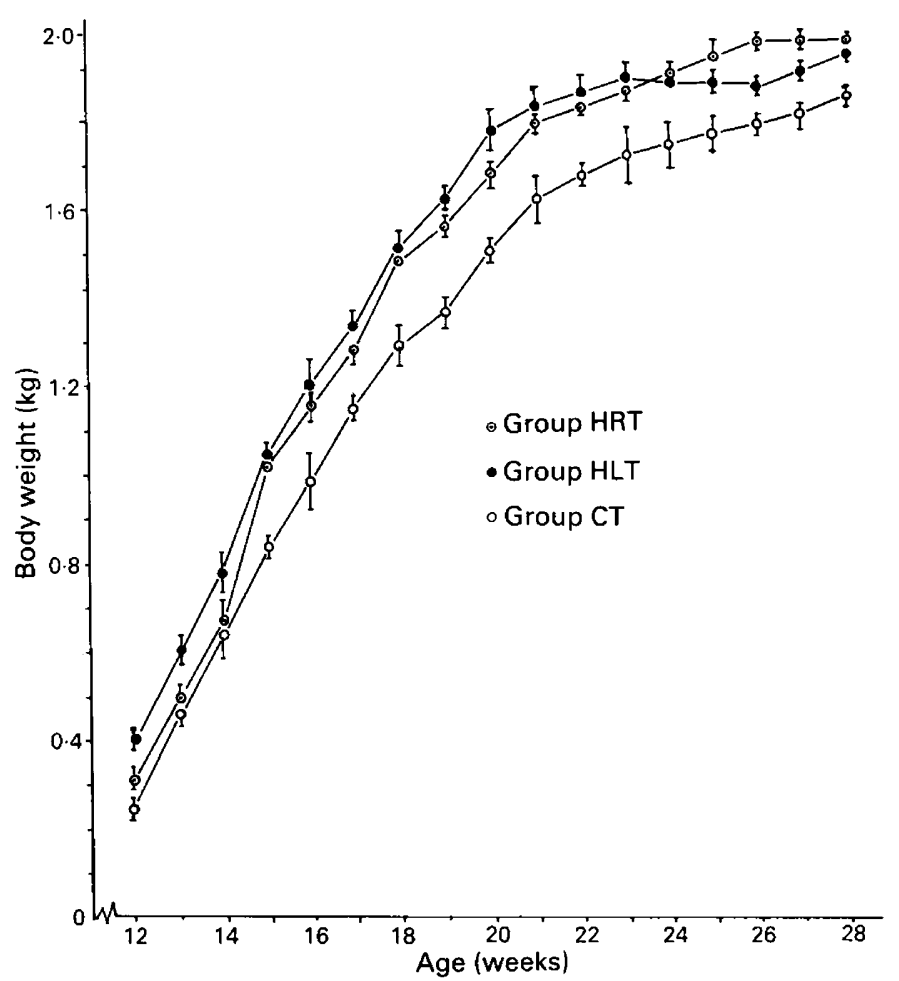

Fig. 1. The body weights of hemicastrated and intact cockerels at different ages. Each value represents the mean \pm s.e.m. of 10 observations.

\section{Results}

The ages at which spermatozoa were found in hemicastrated and intact cockerels are shown in Table 1. Spermatozoa were first observed in the ejaculates of the hemicastrates at 111 days and in the intact cockerels at 121 days of age. 


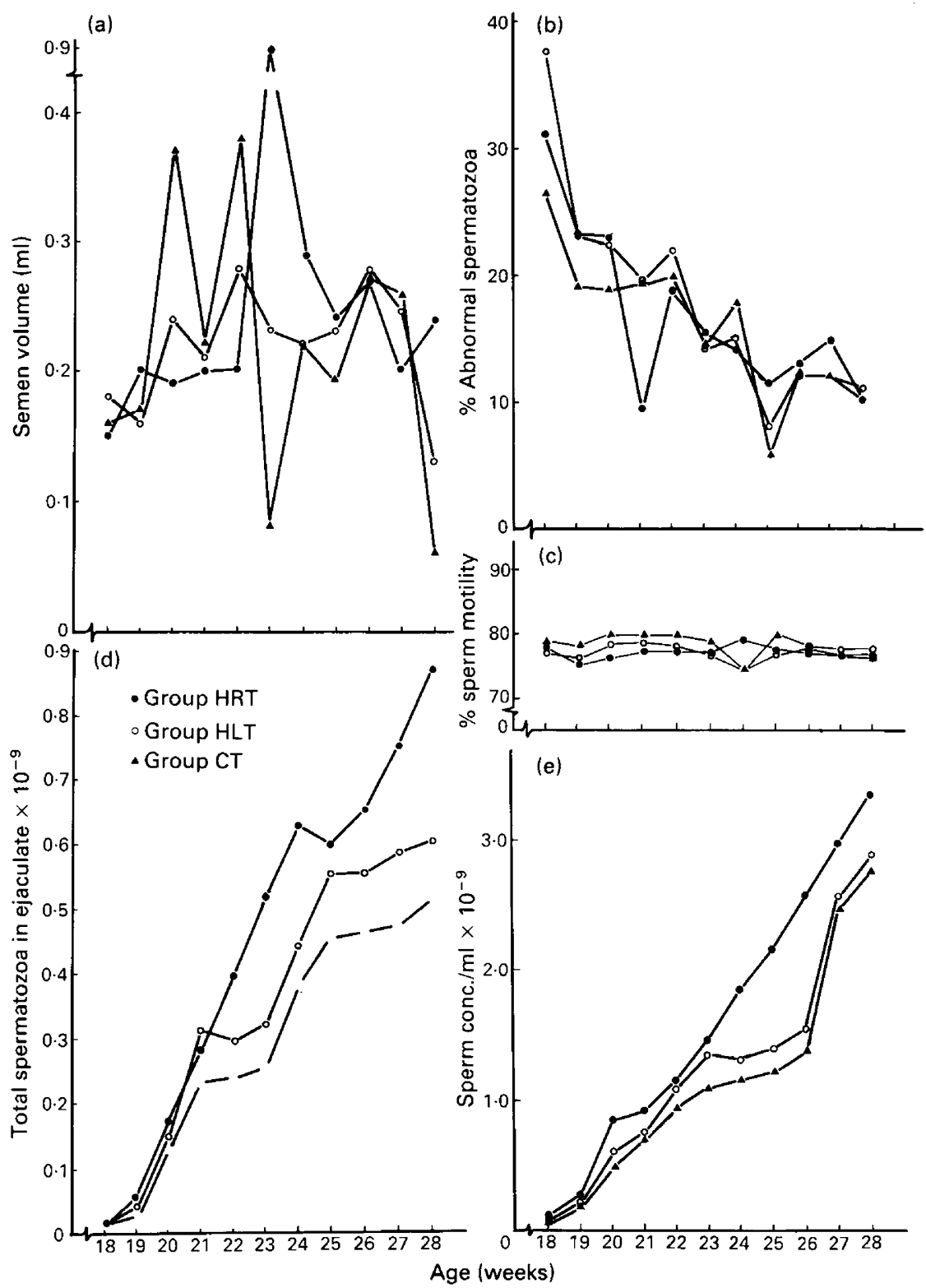

Fig. 2. Values of (a) semen volume, (b) percentage abnormal spermatozoa, (c) percentage motility of spermatozoa, (d) total numbers of spermatozoa and (e) sperm concentration in hemicastrated and intact cockerels at different ages. Values are the mean of 10 observations.

Figure 1 shows the mean of the body weight of hemicastrated and intact cockerels at different ages: between 12 and 28 weeks of age values were higher in hemicastrates $(P<0.01)$ than in the controls. There was no significant difference between the body weights of birds in Groups HRT and HLT.

There was no significant difference between the groups in respect of the volumes of the ejaculates (HRT 0.28 \pm 0.06 ; HLT $0.22 \pm 0.01$; CT $0.22 \pm 0.03 \mathrm{ml}$ ) (Fig. 2a), and percentage of 
abnormal spermatozoa (HRT $1.67 \pm 0 \cdot 2 ;$ HLT $1 \cdot 17 \pm 0 \cdot 25 ;$ CT $1.62 \pm 0 \cdot 16$ ) (Fig. 2b), and percentage motility (HRT 77.8 $\pm 0 \cdot 35$; HLT 77.4 $\pm 0 \cdot 37$; CT 78.28 $\pm 0 \cdot 50$ ) (Fig. 2c).

Sperm concentration (Fig. 2e) increased with age. There was a significant difference between the hemicastrated and the intact cockerels $(P<0.01)$ and between Groups HLT and HRT $(P<0.01)$ $\left(\right.$ HRT $1 \cdot 61 \pm 0 \cdot 11 ;$ HLT $1 \cdot 27 \pm 0 \cdot 26$; CT $1 \cdot 16 \pm 0.26$ spermatozoa $\left./ \mathrm{ml} \times 10^{9}\right)$.

Figure 2(d) shows that the mean total spermatozoa in the ejaculate of each group increased with age. There was a significant difference between the hemicastrates (HRT $0.449 \pm 0.086 \times 10^{9}$; HLT $\left.0.350 \pm 0.064 \times 10^{9}\right)$ and the controls $\left(0.287 \pm 0.054 \times 10^{9}\right)(P<0.01)$, and between the birds in Groups HLT and HRT $(P<0.01)$.

\section{Discussion}

The results of this study show that hemicastrated cockerels produced spermatozoa earlier than did intact cockerels and that all the birds in Group HLT produced spermatozoa before those in Group HRT. These results confirm an earlier report (Onuora, 1987) in which spermatozoa were found in the macerated tissues of the testes of all Group HLT birds earlier than in those of Group HRT, and in those of Group HRT earlier than those of the intact cockerels. The mechanism for the earlier production of spermatozoa is not understood but may be associated with the enhanced spermatogenesis in hemicastrates (Santolaya \& Burgos, 1978; Onuora, 1985) and to differences in the attributable number of 'spare' (functional) receptors and occupancy of LH receptors in the Leydig and Sertoli cells (Sharpe, 1982).

The difference between Groups HRT and HLT may be due to anatomical features. In chicken the number of blood vessels to the left and right gonad is related to their activity (Nickel et al., 1977). Furthermore, at the 4th day of incubation 4-5-fold the number of germ cells migrate to the primordial left testis than to the right testis (Witschi, 1935). The differences may be due to the spatial disposition of the testes with respect to the air sacs, as there have been suggestions that the testes are cooled by these air sacs during thermal control of spermatogenesis (King \& McLelland, 1975).

The mean body weights of the hemicastrates were significantly greater than those of the controls, and Group HRT birds were slightly heavier than those in Group HLT, an observation already reported (Mast et al., 1981; Onuora, 1987). However, Wilson \& de Reviers (1979) did not find any significant difference between the body weights of hemicastrated and intact cockerels.

Hemicastration causes relaxation of the pituitary-gonadal and Sertoli cell-inhibin axes, causing initial reduction in the amount of inhibin and testosterone plasma concentrations (Walton et al., 1978; Droit et al., 1979; de Krester, 1979). The resultant higher concentrations of LH, FSH and testosterone (Franchimont et al., 1978; Cunningham et al., 1978; Wilson \& de Reviers, 1979; Walton et al., 1980) increase the production of both intra- and extra-tubular components and their precursors in the prepubertal testis (de Jong \& Sharpe, 1977; Cunningham et al., 1978). The increased spermatogenic components enhance spermatogenesis with production of more spermatozoa both within the testis (Thyagaraja \& Sakar, 1970; Santolaya \& Burgos, 1978; Hochereau-de Reviers \& Courot, 1978; Onuora, 1987) and extragonadally (Onuora, 1985). Hence the sperm concentration, and the total spermatozoa in the ejaculate, were significantly higher in the hemicastrates than in the intact birds. The rise in the androgen concentration may be responsible for the increased body weight in the hemicastrates.

The difference in the degree of testicular compensatory hypertrophy and the concomittant plasma concentrations of androgen between the hemicastrated and the intact cockerels may explain the presence (Mast et al., 1981; Putra \& Blackshaw, 1982; Onuora, 1987; present study) or absence (Wilson \& de Reviers, 1979) of significant differences between the body weights. However, plasma testosterone concentrations correlate positively with body weights (Gilmore, 1969; Gemmell et al., 1986). 
The results from this study show that the left and right testes have different spermatogenic potentials. Although the left testis produced spermatozoa earlier, the right testis has more spermatogenic activity when total spermatozoa per $\mathrm{mg}$ testis are compared. The mechanisms responsible for these differences are not known and need further investigation.

I thank Mr C. A. Okereke, a final year student in the Faculty of Veterinary Medicine University of Nigeria Nsukka, for help with collection of the data.

\section{References}

Burrows, W.N. \& Quinn, J.P. (1935) A method of obtaining spermatozoa from the domestic fowl. Poult. Sci. $14,251-254$.

Cooper, D.M. \& Rowell, J.G. (1958) Relations between fertility, embryonic survival and some semen characteristics in the chicken. Poult. Sci. 37, 699-707.

Cunningham, G.R., Tindall, D.J., Huckins, C. \& Means A.R. (1978) Mechanism for the testicular hypertrophy which follows hemicastration. Endocrinology 102, 16-23.

de Jong, F.H. \& Sharpe, R.M. (1977) The onset of establishment of spermatogenesis in rats in relation to gonadotrophin and testosterone levels. $J$. Endocr. 75, 197-207.

de Kretser, D.M. (1979) Endocrinology of male infertility. Br. med. Bull. 35, 187-192.

Droit, F.J.M., De Reviers, M. \& Williams, S.J. (1979) Plasma testosterone level in intact and hemicastrated growing cockerels. J. Endocr. 811, 169-171.

Franchimont, P., Demonlin, A., Verstraelen-Proyard, J., Hazee Hagelstein, M.T., Walton, J.C. \& Waites, G.M.H. (1978) Nature and mechanisms of action of inhibin prospective regulation of male fertility. Int. $J$. Androl., Suppl. 2, 69-80.

Gemmell, R.T., Lepon, G. \& Barnes, A. (1986) Weekly variations in body weight and plasma testosterone concentrations in the male possum (Trichosurus vulpecula). Gen. comp. Endocrinol. 62, 1-7.

Gilmore, D.P. (1969) Seasonal reproductive periodicity in the male Australian brush-tailed possum (Trichosurus vulpecula). J. Zool., Lond. 157, 75-98.

Hochereau-de Reviers, M.T. \& Courot, M. (1978) Sertoli celis and development of seminiferous epithelium. Annls Biol. anim. Biochim. Biophys. 18, 573-583.

King, A.S. \& McLelland, J. (1975) Outlines of Avian Anatomy, p. 74. Bailliere Tindall, London.

Mast, M.G., Jordon, H.C. \& McNeil, J.H. (1981) The effect of partial and complete caponization on growth rate, yield and selected physical and sensory attributes of cockerels. Poult. Sci. 60, 1827-1833.
Nickel, R., Schummer, A. \& Serferle, E. (1977) Anatomy of the Domestic Birds, pp. 101-102. Verlag Paul Parey, Berlin.

Onuora, G.I. (1985) Effect of hemicastration on sperm reserves of cockerels on a restricted dietary intake; sperm reserves and deposition of sperm in different strains of cockerels. Anim. Reprod. Sci. 9, 285-293.

Onuora, G.I. (1987) Spermatogenic activities of the left and right testes of hemicastrated and intact cockerels. Anim. Reprod. Sci. 14 (in press).

Putra, D.K.H. \& Blackshaw, A.W. (1982) Morphometric studies of compensatory testicular hypertrophy in the rat after hemicastration. Aust. J. Biol. 35, 287-293.

Romonoff, A.L. (1960) The Avian Embryo, pp. 823-829. Macmillan, London.

Santolaya, R.C. \& Burgos, M.H. (1978) First spermiation and spermatozoa concentrations in hemicastrated rats. Andrologia 10, 26-30.

Sharpe, R.M. (1982) The normal regulation of the Leydig cell. Oxford Rev. Reprod. Biol. 4, 241-317.

Thyagaraja, B.S. \& Saker, H.B.D. (1970) Compensatory hypertrophy of the contralateral testis after unilateral castration in the toad Bufo melanostictus. Experientia 26, $544-545$.

Walton, J.S., Evins, J.D. \& Waites, G.M.H. (1978) Feedback control of FSH in pre- and post-pubertal rams as revealed by hemicastration. $J$. Endocr. 77, 75-84.

Walton, J.S., Evins, J.D., Hillard, M.A. \& Waites, G.M.H. (1980) FSH release in hemicastrated prepubertal rams and its relationship to testicular development. J. Endocr. 84, 141-152.

Wilson, S.C. \& de Reviers, M. (1979) Concentrations of Luteinizing hormone in the plasma of hemicastrated cockerels. J. Endocr. 83, 379-384.

Witschi, E. (1935) Origin of assymetry in the reproductive systems of birds. Am. J. Anat. 56, 119-141.

Received 8 January 1987 